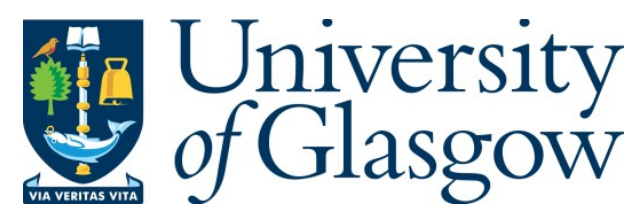

Aleksanyan, M., and Danbolt, J. (2015) Segment reporting: is IFRS 8 really better? Accounting in Europe, 12(1), pp. 37-60.

There may be differences between this version and the published version. You are advised to consult the publisher's version if you wish to cite from it.

http://eprints.gla.ac.uk/103758/

Deposited on: 25 May 2015

Enlighten - Research publications by members of the University of Glasgow http://eprints.gla.ac.uk 


\title{
Segment reporting: Is IFRS 8 really better?
}

\author{
Mark Aleksanyan ${ }^{\mathrm{a}, *}$ and Jo Danbolt ${ }^{\mathrm{b}}$
}

${ }^{a}$ Adam Smith Business School, University of Glasgow, Glasgow, G12 8QQ, UK. E-mail: mark.aleksanyan@glasgow.ac.uk,Tel.: +44 (0) 1413303061.

${ }^{b}$ University of Edinburgh Business School, University of Edinburgh, 29 Buccleuch place, Edinburgh, EH8 9JS, UK. E-mail: jo.danbolt@ed.ac.uk, Tel.: +44(0)131 6502448.

\begin{abstract}
This paper contributes to the debate on segment reporting standards in the UK and Europe and, specifically, the merit of IFRS 8 relative to predecessor standards (SSAP 25 and IAS 14R). We carry out a longitudinal analysis of segment reporting practices of a large sample of listed UK companies, covering all three reporting regimes. Using the Proprietary Cost Theory (PCT) as our theoretical lens, we present evidence consistent with PCT, that proprietary costs considerations influence companies' segment disclosure choices. We show that when companies are required to disclose more detailed accounting information for geographical segments (e.g., when geography is the basis of operating segments, under IFRS 8, or primary segments, under IAS 14R), they choose to define geographical segments in broader geographic areas terms than was the case under SSAP 25. We find that although companies disclose greater quantity of segmental information under IFRS 8 and IAS 14R (than SSAP 25), the more recent standards brought about a notable reduction in (i) the level of specificity of the disclosed geographical segments, and (ii) the quantity of disclosed geographic segment profit data one of the most important data types for users. While this may have reduced the proprietary costs of segment disclosures, the reduction in disclosure of segmental performance data may have reduced the usefulness of segment reports to investors.
\end{abstract}

Keywords: Segment reporting; IFRS 8; IAS 14 Revised; SSAP 25; Geographical disclosures 
JEL Classification: M48, M41 and G38

${ }^{*}$ Correspondence Address: Mark Aleksanyan, Adam Smith Business School, University of Glasgow, Glasgow, G12 8QQ, United Kingdom. E-mail: mark.aleksanyan@glasgow.ac.uk 


\section{Segment reporting: Is IFRS 8 really better?}

\section{Introduction}

Over the past decade, the segment reporting regime for most listed European firms has changed. More specifically in the UK listed companies, standards changed twice: in 2005, when the International Accounting Standard (IAS) 14R replaced the Statement of Standard Accounting Practice (SSAP) 25, and in 2009, when the International Financial Reporting Standard (IFRS) 8 superseded IAS 14R. In this study we carry out a longitudinal analysis of the impact of these successive changes in segment reporting rules on segment disclosures of UK public companies. We examine the impact of these changes in segment reporting rules on the amount and types of segmental information disclosed by companies. Our analysis is based on a balanced sample of the 127 largest listed non-financial UK companies over the period from 2002 to 2010, which covers all three reporting regimes, and allows comparative analysis of segmental disclosures by the same sample of companies under the three standards.

The primary motivation of this study is to contribute to the debate on the merit of the latest standard, IFRS 8, offering evidence to inform policy making. The adoption of IFRS 8 was driven by the convergence agenda between US Statement of Financial Accounting Standards (SFAS) and IFRS (IFRS 8, para IN 2). IFRS 8 is nearly identical to SFAS 131, with only minor differences and changes necessary to make the terminology consistent with IFRS (Crawford, Ferguson, Helliar, and Power, 2014). A highly politicised debate and power struggle between the International Accounting Standards Board (IASB) and the European Union surrounded the standard setting process of IFRS 8 (Veron, 2007; Crawford et al., 2014). The EU was concerned that IFRS 8 would bring an alien US standard, SFAS 131, into EU law (Nichols, Street, and Cereola, 2012). The EU also viewed controversial the standard's use of the management approach to segment identification and reporting, which would allow the use of non-IFRS measures (Veron, 2007). Concerns were also raised in that IFRS 8 would impair the reliability and comparability of segmental information relative to that of IAS 
14R (Veron, 2007). Sukhraj (2007) comments that investors expressed considerable concern about the leeway given to managers in choosing what aspects of the business to report, and were “...perturbed by the removal of geographic segmentation, which they deem is important to them”. ${ }^{1}$ IFRS 8 was adopted by IASB in 2006, and endorsed for all EU countries in 2007, despite concerns among various users in Europe.

Because of these concerns, the European Parliament required the International Accounting Standards Board (IASB) to carry out a post-implementation review (PIR) of IFRS 8. The PIR was completed in July 2013, and concluded that while preparers generally think that the Standard works well, investors' views were mixed (IASB, 2013). In particular, the PIR highlights that "investors are wary of a segmentation process that is based on the management perspective [and] ... mistrust management's intentions and sometimes think that segments are reported in such a way as to obscure the entity's true management structure (often as a result of concerns about commercial sensitivity) or to mask lossmaking activities within individual segments” (IASB, 2013, p. 5). Among other issues revealed by the PIR are IFRS 8's enforcement costs, segment aggregation criteria, and the number and type of line items disclosed (Moldovan, 2014).

While the literature on the implementation of IFRS 8 is growing, as summarised in the PIR (IASB, 2013), only Crawford et al. (2012) provide large-sample evidence of the impact of IFRS 8 on segment reporting in the UK. However, given the timing of Crawford, Extance, Helliar, and Power's (2012) study, they could only adopt a short-term framework and only consider the transition period, covering the last year of IAS 14R and the first year of IFRS 8. Crawford et al.'s (2012, p. 8) call to extend the review of the impact of IFRS 8 by using a longer time span than just one-year pre vs. one-year post analysis. Our study contributes to the literature by responding to this call for further research. Clearly, the merit of IFRS 8 can be better understood by considering it within its historical context, by comparing it with both IAS 14R and SSAP 25.

We seek to uncover changes in qualitative and quantitative features of disclosed segmental 
information, by answering the following research questions: To what extent did each successive standard affect (1) the number and types of reported segments; (2) the way geographic areas are defined and reported; and (3) the volume and nature of accounting information disclosed in segment reports?

This study contributes to the extant literature on financial disclosures in several ways. First, unlike prior studies, we evaluate the merits of IFRS 8 relative to all of its predecessors in the UK (SSAP 25 and IAS 14R). We do so by comparing important qualitative and quantitative features of the segmental information actually disclosed by the UK companies under each standard. These standards differ fundamentally in a number of ways, including how reportable segments are to be identified, what accounting line item information is to be disclosed for specific types of reportable segments, and whether segmental amounts are required to conform with the basis of preparation and reporting of the entity's financial statement. The advantage of analysing disclosure under three standards over a long timescale lies in its potential to uncover new phenomena that a study of single reporting regime may not be able to reveal.

Second, we explicitly consider in the analysis how companies responded to or interpreted IFRS 8's entity-wide information disclosure requirement, an aspect that has not been explicitly addressed by studies summarised in the PIR. We show that it is important to distinguish between broad (operating segments and entity-wide) and narrow (operating segments only) interpretation of geographic and business information disclosed in segmental reports under IFRS 8, because this would affect conclusions about the merit of IFRS 8 relative to IAS 14R and SSAP 25.

Third, we deploy the Proprietary Cost Theory (PCT) as our theoretical lens to evaluate and interpret some of our important findings. Extant segment disclosure literature uses PCT to theorise management's segmental disclosure incentives, and documents empirical evidence consistent with PCT (e.g., Harris, 1998; Leuz, 2004; Ettredge, Kwon, Smith, and Stone, 2006; Berger and Hann, 2007). Proprietary costs are regarded as an important cost of segmental disclosure regulations (Leuz, 
2004). We show the proprietary cost incentives are at play in the UK in a similar vein, as they are shown to be in non-UK segment disclosure literature. However, while in non-UK literature the proprietary cost argument has been mainly applied when analysing companies' line-of-business segment disclosures, our study highlights the relevance of the proprietary cost argument to companies’ geographic information disclosure choices.

One of our most revealing findings is that when companies are required to disclose more detailed accounting information for geographical segments (e.g., when they designate geography as their operating segments, under IFRS 8, or primary segments, under IAS 14R), the geographical segments tend to be defined in terms of broader geographic areas. Similarly, the geographic segments reported as operating and primary segments under IFRS 8 and IAS 14R, tend to be defined as broader geographical areas than were geographic segments disclosed by the same companies under SSAP 25. Such evidence is consistent with predictions from PCT, with companies reducing proprietary costs associated with disclosure of commercially sensitive information (e.g., profitability of operations in specific geographic countries) by disclosing more broadly-defined geographic areas. We also show that the vast majority of our sample companies (77\%) choose business rather than geography as their primary (operating) segments under IAS 14R (IFRS8). Given the substantially more onerous disclosure requirements of accounting information for the primary/operating segments, the prevalence of this choice by companies corroborates our conclusion that geographical information is proprietary cost laden. These findings complement prior literature on the impact of competitive disadvantage on managers' business segment reporting choices (Harris, 1998; Botosan and Stanford, 2005) by revealing similar behaviour in relation to geographic segment reporting choices.

We also find that while IAS 14R and IFRS 8 surpass SSAP 25 in terms of the overall quantity of accounting information disclosed in companies' segment reports, a significantly lower quantity of segmental profit information - arguably the most important accounting information type for investors - was disclosed under IAS 14R and IFRS 8, for both line-of-business (LOB) and, even more significantly, geographic segments. Furthermore, IFRS 8 resulted in a major decline in the average 
number of reported segments when the operating segments are LOB, but more notably so when the operating segments are geographic. These findings speak to the concerns expressed by users who viewed the potential reduction of geographic data as one of the main problem areas of IFRS 8 (IASB, 2013, p. 10).

Overall, we conclude that despite the possible benefits associated with (i) the increased quantity of information disclosed under IFRS 8, and (ii) the fact that IFRS 8 allows investors to see companies through the eyes of management, SSAP 25 would arguably better serve investors' needs for geographic information.

The paper is organised as follows. Section 2 reviews segment reporting standards and discusses the prior relevant research. Section 3 outlines key research questions. Section 4 describes the sample and our approach to analysis. Section 5 discusses the results, and Section 6 concludes.

\section{Background and prior research on segment reporting standards}

Academic- and practitioner-oriented research is replete with evidence that corporate segment information is vitally important to financial statements users and investors alike. According to the Association of Investment Management and Research’s (AIMR, 1993) study of US analysts, and PwC's (2007) survey of analysts in a number of major capital markets, financial analysts regard segment information as indispensable to investment analysis. Similarly, the European analysts' group, as cited by Street and Nichols (2002), argues that segment reporting enables users to better understand an enterprise's past performance, and facilitates judgements about the enterprise as a whole, including better assessing risks and prospects. ${ }^{2}$

To address users' demand for quality segment information, accounting standard setters and regulators around the world have been introducing and updating segment reporting standards. In the UK, the London Stock Exchange has since 1965 required listed firms to disclose some limited segment-level information, e.g., turnover and profits by line-of-business (LOB). ${ }^{3}$ More detailed requirements 
emerged under the 1981 Companies Act, which required companies to disclose turnover by class of business and geographic market for 'material' segments. Although the Act stated that reportable segments should be "substantially different from each other", it provided little guidance as to what would constitute a reportable business or geographic segment, leaving this to the discretion of firms' directors.

\section{SSAP 25}

The first segment reporting standard in the UK, SSAP 25, was issued in June 1990, by the UK Accounting Standards Committee. Its objective was to increase the volume of segment disclosure and bring more clarity and consistency to the segment reporting practices of UK firms. The standard established a framework for segment identification and reporting whereby segments had to be determined on the basis of differences in returns on investments, degrees of risk, growth rates and future potential. SSAP 25 was prescriptive and required disclosure of geographic and business types of segments, for which essentially the same set of accounting line item information (i.e., turnover, profit before taxation and net assets for each reported segment, and reconciliations of segmental amounts to consolidated totals) had to be disclosed. A $10 \%$ materiality rule applied, with segments having to be disclosed if they accounted for more than $10 \%$ of company sales, profits or assets.

SSAP 25 was very similar to its international contemporaries, IAS 14 (the first segment reporting standard issued by the International Accounting Standards Committee (IASC) in 1981) and SFAS 14 (the first US segment reporting standard issued by the Financial Accounting Standards Board (FASB) in 1976), as all three standards required reporting of geographic and business segments and disclosure of segment revenues, profits and assets for each reportable segment. ${ }^{4}$

While SSAP 25 was considered a step towards more comprehensive and systematic disclosure, it was criticised by academic writers (e.g., Emmanuel and Garrod, 1992) for lacking clear-cut guidance in defining, identifying and presenting segment information, and the latitude in language which allowed for multiple interpretations. Prior research documents mixed evidence as to whether the introduction 
of SSAP 25 led to improvements in the segment disclosure practices of UK firms. Several studies find that the adoption of SSAP 25 was associated with changes in reporting patterns and volume of disclosure (e.g., Emmanuel, Garrod, McCallum, and Rennie, 1999; Emmanuel and Garrod, 1999, 2002). Emmanuel et al. (1999) report that the introduction of the standard led to an increase in the volume of disclosure, notably information on net assets, but that over time growing familiarity with the standard led to a subsequent decline in the level of detail of disclosures, particularly with regard to geographic segments. Companies were found to be particularly sensitive to providing return information for small segments, as this might provide commercially sensitive return information on single investment projects. They conclude that the $10 \%$ materiality rule was mainly used to identify fewer but larger segments, contrary to the intention of the standard. They emphasise and critique the ambiguity in the wording of the standard, as it is not clear whether directors should select any one of the criteria - turnover, results or net assets - in applying the $10 \%$ rule to identify reportable segments, or whether companies are at liberty to only disclose segments exceeding the $10 \%$ threshold based on all three criteria.

Substantial criticism was also levelled against IAS 14 and SFAS 14 (AIMR, 1993; McConnell and Pacter, 1995; Harris, 1998; Street, Nichols, and Gray, 2000; Street and Nichols, 2002; Botosan and Stanford, 2005; Nichols and Street, 2007). Much like SSAP 25, these standards were criticised for the lack of clear guidance in defining reportable segment, allowing managers to aggregate segments in a way that could conceal sensitive proprietary information. They were also criticised for requiring insufficient data items for each segment, and the fact that the reported segments may not reflect the entity’s internal organisation and reporting.

IAS $14 R$

In response to the above criticism and the calls of user groups for higher-quality segmental information, in 1997 the International Accounting Standards Committee issued IAS 14R as a substantial revision of the original IAS 14, introduced in 1981. Similarly, in 1997 the US Financial Accounting Standards Board issued a new standard, SFAS 131, which replaced SFAS $14 .{ }^{5}$ No 
changes were made to segment reporting rules in the UK at that time. However, in 2005, IFRS became compulsory for UK listed companies, and as a result IAS 14R replaced SSAP 25 as the appropriate segment reporting standard for listed UK companies.

IAS 14R introduced two-tier segmentation, where two sets of segments, primary and secondary, had to be identified and reported. If the primary basis of segmentation was line-of-business, the secondary segments had to be geographic, and vice versa. Substantially more accounting data had to be disclosed for primary than for secondary segments. IAS 14R (para. 27) requires segments to be identified based on the entity's internal organisational and management structure and its system of internal financial reporting to key management personnel. A brief summary of the key features of SSAP 25, IAS 14R and IFRS 8 is provided in the Appendix.

No prior study has assessed the impact of the transition from SSAP 25 to IAS $14 \mathrm{R}$ on segment reporting in the UK. Our research addresses this void. However, as SSAP 25 is very similar to IAS 14, a brief review of prior literature on the transition from IAS 14 to IAS 14R may be appropriate. Street and Nichols (2002) examine its impact for a global sample of companies that report under IAS and find that IAS 14R resulted in a significant increase in the number of items of information disclosed for each primary and secondary segment, and a decline in the number of companies claiming to operate in a single line-of-business. However, in geographic segment reporting, many companies continue to utilise the broad, vague geographic groupings for which the original version of IAS 14 was often criticised. Prather-Kinsey and Meek (2004) also study the impact of the transition to IAS 14R and find that it resulted in no loss of information disclosed for LOB and geographic segments. They find no evidence of a decrease in the disclosure of segmental earnings, even though IAS $14 \mathrm{R}$ no longer required it for secondary segments. They also find that IAS $14 \mathrm{R}$ marginally increased the number of LOB and geographic segments, and that more information was disclosed, especially for LOB segments. 
In 2006, the IASB issued a new segment reporting standard, IFRS 8, which became effective in 2009, replacing IAS 14R. IFRS 8 adopted the management approach, requiring companies to disclose operating segments as used for internal reporting and decision making by the chief operating decision maker (CODM), thus allowing the use of non-IFRS measures. The standard also requires disclosure of additional entity-wide information on the entity's products and services, geographical areas, and main customers. In essence, IFRS 8 requires the reporting of the same operating segment and entitywide information as SFAS $131 .^{6}$ The decision to adopt IFRS 8 was motivated by the IASB-FASB convergence agenda (IFRS 8, para. IN2). Despite the rationales provided by the IASB in favour of IFRS 8 (including benefits of international harmonisation; users' ability to see the enterprise through the eyes of the management; and evidence from US studies showing improved segment disclosures and value relevance of segmental data under SFAS 131), the adoption of the standard was met with opposition in Europe. ${ }^{7}$ In April 2007, the Economic and Monetary Affairs Committee of the European Parliament proposed a motion for a parliamentary resolution that expressed significant concerns about the adoption of IFRS 8 in Europe (The Committee on Economic and Monetary Affairs, 2007). The motion expressed concerns including: that IFRS 8 would import an alien standard (SFAS 131) into EU law; that IFRS 8 was a move away from a regime which clearly defines how listed EU companies should define and report on segments, towards an approach that permits management itself to define operating segments as it finds suitable; and that disclosure of geographic information would be reduced compared to IAS 14R.

In their analysis of the comment letters received on IFRS 8's exposure draft (ED 8), Crawford, Helliar, and Power (2013) find that preparers thought that the proposed standard would be more useful to users, but expressed concerns about the cost of information production and disclosure of proprietary information. On the other hand, users perceived a negative impact on them, and expressed concerns about the usefulness of segmental information under IFRS 8. Crawford et al. (2013) also argue that IFRS 8's requirement to disclose information that has been prepared for internal decision making rather than external users is in conflict with the objective of the IASB's conceptual framework, which gives primacy to existing and potential investors. In his September 2007 
presentation to the Economic and Monetary Affairs Committee of the European Parliament, Veron (2007) argues that the IASB's decision to adopt IFRS 8 was a political one. He argues that since IFRS 8 does not require companies to disclose geographic segment information, investors believed that the purpose of IFRS 8 was to narrow differences between the US GAAP and IFRS, rather than to improve the quality of disclosure. Similar criticism was voiced in the UK, when in April 2007, 36 members of the UK Parliament submitted a Parliamentary Motion urging the UK government and the European Commission to carry out an urgent and comprehensive assessment of IFRS 8 (Mitchell, 2007). Concerns were also raised in the financial press. Critics of the standard put pressure on the European Parliament, which instructed the European Commission to conduct a thorough impact assessment of IFRS 8 before it was prepared to act on final endorsement (Zeff, 2008). Eventually, IFRS 8 was endorsed and superseded IAS 14R. It became effective for financial years commencing on or after 1 January 2009.

Nichols, Street, and Tarca (2013) summarise the results of the most recent studies on the impact of IFRS 8 in different countries, and conclude that while IASB anticipated an increase in the number of reported segments following the adoption of the standard, the majority of companies did not change the number of segments. Moldovan (2014) examines a sample of 400 European multi-segment companies in the first year of IFRS 8 adoption and documents inconsistencies with which companies disclose their segmental and entity-wide information in the notes to financial statements relative to other corporate-level communications (e.g., press releases, corporate websites, webcasts, etc.). However, research on the impact of IFRS 8 implementation is still in its infancy. Research into the impact of IFRS 8 on companies in the UK is limited to a report by Crawford et al. (2012), in which they compare segment reporting during the last year of IAS 14R (2008) and the first year of IFRS 8 (2009) implementation. ${ }^{8}$ They also interview a small sample of users, preparers and auditors to gather opinions on whether IFRS 8 provided more decision-useful information than IAS 14R. Crawford et al. (2012) find that while the number of segments increased, the line items per segment on average decreased. ${ }^{9}$ However, their analysis only covers the latest segment regime change. In contrast, our study employs a longer-term framework and compares segment reporting practices under all three 
segment reporting regimes. This helps to achieve a better understanding of how segment disclosure in the UK has changed with the move to a management approach in segment reporting. In addition to analysing the impact of changes in segment reporting standards on geographic vs. business line disclosures, we focus explicitly on the provision of segment profit data, given the importance of corporate performance for investors and analysts (AIMR, 1993; PwC, 2007).

Segment disclosure literature reveals the trade-off between the benefits and costs of segment disclosure regulation for companies (e.g., Leuz, 2004). The benefits include reduction in information asymmetry, which can lower companies' cost of capital (i.e., capital-market considerations). Segment disclosure regulations are primarily motivated by such capital-market considerations. Had there been no disclosure costs, full disclosure of information should prevail. However, extant disclosure literature demonstrates that proprietary cost (i.e., disadvantages associated with disclosure of competitively sensitive information) is the key factor that deters companies from full disclosure, as companies are found to be reporting segments in line with their proprietary cost incentives (Harris, 1998; Leuz, 2004; Ettredge et al., 2006; Berger and Hann, 2007). In a UK survey of corporate managers' disclosure attitudes, Gray and Robers (1988) report that segment disclosures are perceived as among the most highly sensitive items, and that managers' assessment critically depends on the level of segment aggregation. In a US survey of corporate managers, Smiley (1988) finds that $79 \%$ of corporate managers use the masking of a division's profitability as the most frequent strategy for deterring entry by competitors. André et al. (2014) study segment disclosure choices of 270 companies from $17 \mathrm{EU}$ countries in the first year of IFRS 8 adoption, and show that proprietary concerns are important, and solved in different ways - either by not following the standard's suggestions for disclosure quantity, or by applying discretion in operating segment aggregation. The proprietary cost hypothesis, attributed to Verrecchia (1983) and later becoming known as proprietary cost theory, hinges on the premise that full disclosure of information may be costly for the disclosing entities as it may reveal commercially sensitive information to competitors and disadvantage the entity's business. Because proprietary cost is potentially the main significant cost that influences companies' segmental disclosure decisions, we use PCT as our main conceptual framework for 
rationalising and interpreting the segment disclosure choices that our sample companies have been making across the three segment reporting regimes. ${ }^{10}$

\section{Research questions}

While the discussion in the preceding section demonstrates that the intent of each new standard was to improve segment disclosures, the extent to which changes in segment reporting standards improved the disclosure practices of companies is an empirical question. Research on segment reporting under US GAAP is extensive, and much empirical evidence exists with regard to the actual impact of SFAS 14 vs. SFAS 131. However, less is known about the relative impact of each of the three successive standards (SSAP 25 vs. IAS 14R vs. IFRS 8) on UK listed companies.

Our study provides a comprehensive empirical assessment of the extent and nature of the impact of all three standards on segment disclosure practices in the UK. The following research questions (RQs) are addressed in this study:

RQ1. To what extent did each successive standard - SSAP 25, IAS 14R and IFRS 8 - affect the number of business and geographic segments reported by UK companies?

RQ2. To what extent did the adoption of each successive standard affect the level of specificity with which geographic areas are defined (e.g., specific country or countries, broader regions or continents)?

RQ3. To what extent did each successive standard affect the type and volume of segmental accounting information disclosed?

We next discuss the research design and sample employed to answer the research questions.

\section{Sample and method}

Segment reporting data on UK public companies is hand-collected from the notes to the financial statements of the respective companies' published annual reports. The annual reports were obtained from the Perfect Information Filings database or downloaded from the companies' websites. Our analysis is based on seven years of data during the 2002 to 2010 period. The sample period covers the 
last three years of the SSAP 25 era (2002 through 2004), three years of the IAS 14R era (years 2006 through 2008) and one year (2010) of the IFRS 8 era. We exclude 2005 and 2009 from the analysis given that these are transition years, with different companies reporting under different standards. The sample consists of non-financial companies that were constituents of the FTSE 100 index at least once during the 2002-2010 period. To ensure that any observed changes in companies' segment reporting practices over time are not driven by changes in sample composition, we restrict our sample to firms for which we have data for each of the seven years of analysis. Our analysis is therefore based on a balanced sample of 127 companies per year, giving a total of 889 firm-year observations. ${ }^{11}$

While $L O B$ and geographic segmentation is required under SSAP 25 and IAS 14R, IFRS 8 requires reporting of operating segments, and does not specify whether these should be based on lines of business or geography. As stated in IFRS 8 (paragraph 5), operating segments are those components of a company whose operating results are regularly reviewed by the entity's chief operating decision maker and for which discrete financial information is available. In addition, entity-wide disclosures are required (IFRS 8, paragraphs 31-34), which should include information on geographic areas, products and services, and major customers.

As discussed by Crawford et al. (2012, pp. 7-8), there is "a great deal of confusion among the respondents about the new category of 'entity-wide disclosures' which were mandated under IFRS 8. Users, in particular, either did not know what these were or equated them with geographic disclosures which had previously been provided as segment data under IAS 14R”. Consequently, Crawford et al. (2012) treat entity-wide disclosures under IFRS 8 as equivalent to secondary segments under IAS 14R. When collecting our data, it similarly became apparent that a large proportion of our sample companies simply reported as entity-wide disclosures what had previously been reported as secondary segments under IAS 14R. More specifically, the secondary LOB segments reported under IAS 14R formed the basis for the reporting of products and services entity-wide information under IFRS 8 and, similarly, the secondary geographic segments disclosed under IAS 14R were usually translated into 'geographic areas’ disclosed as entity-wide information under IFRS 8. 
For example, in 2008 (under IAS 14R), HomeServe Plc reported four primary geographic segments (UK Emergency Services; UK Policy Membership; USA; Continental Europe) and two secondary LOB segments (Provision of repair services; Sale of home assistance \& emergency policies), and in 2010 (under IFRS 8), the company reported the four geographic segments as ‘operating’ segments and the LOB segments as entity-wide 'product \& services' disclosures. Similarly, in 2008, Antofagasta Plc reported seven primary LOB segments and 13 geographic secondary segments, and in 2010 'translated' the seven LOB segments into 'operating' segments, and nine of the 13 geographic segments into entity-wide disclosure of geographic areas.

To account for the preparers' and users' tendency to treat entity-wide disclosures as segments, we compute and report two alternative measures ('narrow' and 'broad') of the number of segments reported under IFRS 8. Under the 'narrow' measure, only the reported operating segments are counted as segments. Under the 'broad' measure, in addition to the reported operating segments, the entitywide (geographic and products/services) disclosures are also treated as segments, as follows:

(i) if the nature of the reported operating segments is line-of-business, both the operating segments and any products/services reported under entity-wide disclosure are treated as LOB segments. ${ }^{12}$ Any geographic locations reported under entity-wide disclosure are treated as geographic segments.

(ii) if the nature of the reported operating segments is geographic, both the operating segments and any geographic locations reported under entity-wide disclosure are treated as geographic segments. Any products/services reported under entity-wide disclosure are treated as LOB segments.

Using the example of Antofagasta Plc, under the narrow measure the company would report seven LOB segments and no geographic segments. Under the broad measure, we add the four products/services reported in entity-wide disclosures to the LOB segments, giving a total of 11, while the nine geographic areas are treated as geographic segments. We fully acknowledge that entity-wide 
disclosures are strictly speaking not segments. Our treatment of entity-wide disclosures as segments, under our broad categorisation, may result in some over-estimation of the number of segments, to the degree that there is overlap between the business operating segments and products/services disclosed in entity-wide disclosures. However, a narrow approach, focusing only on formal segments, may be too restrictive, as the majority of companies appear to treat entity-wide disclosures as equivalent to what were secondary segments under IAS 14R. We therefore use both the narrow and broad approaches in our analysis.

The first research question (RQ1) implies a method of counting and comparing the number of segments across different segment types and reporting standards. We compare the changes that occurred during periods when there was no change in segment regime with those that occurred during periods when the segment reporting standard changed. The four periods are:

1. The SSAP 25 period: year 2002 vs. 2004

2. The SSAP 25 to IAS 14R changeover period: year 2004 vs. 2006

3. The IAS 14R period: year 2006 vs. 2008

4. The IAS 14R to IFRS 8 changeover period: year 2008 vs. 2010

To address RQ2, regarding the impact of successive standards on how companies define their geographic areas, the disclosed geographic area names are classified into the following five categories, according to how narrowly the geographic areas are identified:

1. Specific single-country segments (e.g., 'UK', 'France’, etc.)

2. Specific two-country segments (e.g., 'UK and Ireland’, 'USA and Canada', etc.)

3. Specific single-region or single-continent segments (e.g., 'Continental Europe', 'Rest of Europe’, etc.)

4. Specific two-or-more-regions or two-or-more-continents segments (e.g., 'Middle East and Africa', 'Africa, Asia, Australasia and Other America', etc.). This also includes segment names that represent a combination of a country and a region/continent that does not include that country (e.g., 'Asia and USA', etc.) 
5. Rest of the world segments. This includes segments whose names include unidentifiable geographic locations (e.g., 'Rest of World', 'Other international', etc.)

To address RQ3, regarding the extent to which each successive standard affected the type and volume of segmental accounting information disclosed, we measure the overall volume of segmental accounting information disclosed by a firm as the total number of all segmental accounting line items disclosed for all reported segments. Under the narrow approach, we only count the accounting line items on operating segments under IFRS 8, while under the broad approach we also include the accounting line items in the entity-wide disclosures. The total number of reported segmental accounting line items categorised by type (e.g., sales, assets, profits) is our measure of the volume of that type of segmental accounting information disclosed by companies. ${ }^{13}$

\section{Results and discussion}

\subsection{Changes in the number of segments reported}

To address RQ1, we first examine the impact of each successive standard on the number of segments reported per firm. Table 1 reports the average number of total, LOB and geographic segments disclosed by firms in each year. ${ }^{14}$

Table 1 about here

Data in the upper panel of Table 1 show that across all three standards about half of all disclosed segments were geographic and half were LOB. The average total number of segments reported per firm during the IAS 14R period varied between 7.2 and 7.3, which is marginally (but not statistically significantly) higher than the total number of segments reported under SSAP 25 (between 7.0 and 7.2 per firm). Similarly, there were no statistically or economically significant differences between SSAP 25 and IAS 14R periods in terms of geographic and LOB segment numbers. However, there was a sharp and statistically significant reduction in the overall number of reported segments, from 7.2 in 2008, under IAS 14R, to 4 in 2010, under IFRS 8. There was a marked and statistically significant 
reduction in the number of LOB segments, from 3.5 in 2008 to 2.9 in 2010, and a more dramatic reduction in geographic segments, from 3.7 in 2008 to just 1.1 in 2010. Thus, we document evidence which seems to be in sharp contrast with that summarised and reported in IASB's postimplementation review of IFRS 8, which states "Our review of academic research confirmed that although the number of reported segments did not change in many jurisdictions, when the number of reported segments did change, the number generally increased.” (IASB, 2013, p. 6).

While it is plausible that IFRS 8 had a differential impact on the number of segments in different jurisdictions, another reason is that the academic papers reviewed and summarised in the PIR and the research review by Nichols et al. (2013) provided little if any articulation on how they interpreted the entity-wide disclosure (e.g., Crawford et al., 2012). Indeed, under our broad measure of segment count, which treats entity-wide disclosures as segments, our results become consistent with those summarised in the PIR. More specifically, our broad measure of segment count would result in a large and statistically significant increase in the average number of segments per firm, to 8.8 (in 2010, under IFRS 8), with LOB and geographic segments increasing to 4.3 and 4.5, respectively.

Further analysis (middle and lower panels of Table 1) reveals systematic and statistically significant differences in the number of reported geographic, LOB and total segments between firms, with LOB vis-à-vis geography as the primary basis of segmentation under IAS $14 \mathrm{R} .{ }^{15}$ The 29 firms (23\% of the sample) with geography as the primary basis under IAS 14R reported significantly lower numbers of total and LOB segments across all three reporting regimes than did the 98 firms (77\% of the sample) with LOB as the primary basis of segmentation.

Because of somewhat ambiguous wording of the guiding principles of segmentation (such as reference to the internal organisational and reporting structure) in the IAS 14R standard, firms had some leeway in determining their basis of segmentation. The fact that $77 \%$ of firms used LOB and only $23 \%$ used geography as the primary basis could suggest that the majority of companies were less inclined to disclose comprehensive geographic data than LOB data. ${ }^{16}$ Recall that IAS $14 \mathrm{R}$ required 
the disclosure of a substantially greater volume of accounting information for primary segments than secondary segments. This reporting behaviour could be rationalised through the lens of the Proprietary Costs Theory, if one assumes that geographic financial data that reveals performance at specific geographic locations is perceived by companies to be more commercially sensitive than LOB financial data. A potential proprietary cost is any possible reduction in future benefit attributable to a disclosure. Disclosure of accounting data about a company may be useful to competitors and investors in a way which is harmful to a company's prospects even if (or because) the information is favourable (Verrecchia, 1983). Managers face a trade-off between proprietary costs and investors' adverse reaction to limited disclosures by companies, and, according to Scott (1994), exercise discretion by comparing the costs of disclosing proprietary information against the anticipated reduction in company value resulting from investors' perceptions about what may be hidden. Indeed, disclosure of detailed financial information on specific geographic operations could compromise the company's competitive position in the given location and also alert various national tax authorities to regions with particularly high (or low) profitability.

Overall, these results indicate that while the adoption of IAS 14R had no real impact on the number of LOB, geographic or total segments reported per firm, the impact of IFRS 8 depends on the treatment of entity-wide disclosures. Compared to SSAP 25 and IAS 14R periods, IFRS 8 did result in a substantial and statistically significant decrease (increase) in the number of segments under the narrow (broad) definition of segments. There are also persistent and significant differences in the number of segments between the primary-in-geography vis-à-vis primary-in-LOB firms. Results also suggest that the UK companies are more cautious about reporting a segmental organisational structure that would require disclosure of detailed financial information on geographic segments.

\subsection{Changes in the level of specificity of geographic segments}

This section addresses the second research question (RQ2) and examines the impact of the successive standards on the level of specificity of the reported geographic segments/areas. Firms have discretion in determining the degree of specificity of geographic segments or areas for reporting purposes. On 
the one hand, excessive aggregation of heterogeneous geographic areas into one reportable geographic segment or area reduces the level of detail of geographic information and may reduce the usefulness of this information for investors. On the other hand, the more specific the definition of a reported geographic segment is (e.g., a specific country), potentially the more prejudicial to the firm's business the disclosure of such segmental data is likely to be. Table 2 shows the levels of specificity of geographic segments reported under each successive standard.

Table 2 about here

The results for the entire sample (see upper panel of Table 2) show that across all reporting standards, the vast majority of the reported geographic segments and areas were defined in broader than singlecountry terms. Across all regimes, only about a quarter of the reported geographic segments were defined in single-country terms. Single-country segments accounted for $27-30 \%$ of geographic segments reported during the SSAP 25 and IAS 14R periods, and 24\% under IFRS 8. Under our broad approach, the reported single-country segments and areas account for $43 \%$ of all segment and entitywide geographic areas reported. This seems to suggest that while the adoption of IAS 14R did not result in any notable changes in the level of specificity of the reported geographic segments, IFRS 8 increased the disclosure of single-country segments and areas, if one adopts the broad approach. These findings are consistent with those of Nichols et al. (2012) for Continental European companies. However, the data in the two rightmost columns of Table 2 suggest that the increase in specificity amongst our sample firms was driven entirely by IFRS 8's entity-wide disclosure requirements for domestic and individual material foreign countries. Importantly, the results in the middle and lower panels of the table show that the increased disclosure of single-country areas only occurs in firms that used LOB as the primary basis of segmentation under IAS 14R (or continued to use LOB as their operating segments under IFRS 8). More specifically, the percentage of single-country segments reported by primary-in-LOB firms increased marginally upon the adoption of IAS 14R, and there was a more substantial increase of entity-wide single-country areas reported under IFRS 8 (see middle panel of Table 2). 
Opposite patterns are observed in primary-in-geography firms and firms that used geography as their operating segments under IFRS 8 (see lower panel of Table 2). That is, IAS 14R resulted in a major reduction in reported single-country segments, from about 30\% during SSAP 25 to less than 20\% during the IAS 14R and IFRS 8 periods.

The above patterns reveal that companies choose to reduce the disclosure of single-country geographic segments, and increase the disclosure of multi-country segments, when standards require disclosure of a substantially greater amount of accounting information per reportable geographic segment. Notably, this change in disclosure pattern occurred only upon the transition to IAS 14R (and remained unchanged upon transition to IFRS 8), which requires a much greater range of accounting data items to be disclosed per reported primary segment (and operating segments under IFRS 8) than what was required under SSAP 25.

This disclosure behaviour echoes the concerns of investors summarised in the IASB's postimplementation review: "some investors are wary of a segmentation process that is based on the management perspective... [and] mistrust management's intentions and sometimes think that segments are reported in such a way as to obscure the entity's true management structure (often as a result of concerns about commercial sensitivity) or to mask loss-making activities within individual segments" (IASB, 2013, p. 5). Accordingly, this disclosure behaviour can be rationalised through the Proprietary Cost Theory. The increased disclosure requirement of accounting items for primary and operating segments under IAS 14R and IFRS 8 increases the risk of disclosure of segment-level proprietary information. The more specific the reported geographic segments are, the higher the companies' risk (and cost) of proprietary information disclosure. To reduce the increased risk of proprietary information disclosure under IAS 14R's and IFRS 8's increased disclosure requirements (while remaining compliant with the standards' requirements for more accounting information per segment), companies opt for more broadly-defined geographic segments. 
This conclusion is consistent with the findings of Armitage and Marston's (2008) interviews with UK finance directors. They found that there is certain information that companies in general do not want to disclose because it is too useful to competitors, including “...details of performance by business segment, subsidiary or country...” (Armitage and Marston, 2008, p. 328).

Overall, these results suggest that the majority of reported geographic segments are defined by firms in broadly aggregated geographic terms, and that the tendency of doing so after the introduction of IAS $14 \mathrm{R}$ and then IFRS 8 increased (decreased) among those firms that adopted geography (LOB) as the primary basis of segmentation.

\subsection{Volume of segmental accounting information}

Research question 3 (RQ3) addresses the impact of each successive standard on the volume of disclosed segmental accounting information.

Table 3 about here

Categories 1 to 6 and 11 (and Categories 1 to 11) of Table 3 show the volume of different types of mandatory accounting information disclosed during the SSAP 25 (IAS 14R and IFRS 8) period. (accounting information disclosure requirements are summarised in the Appendix). Category 12 captures the volume of non-mandatory accounting information, and Category 13 shows the total volume of disclosed accounting information (sum total of Categories 11 and 12).

Overall, the results in Table 3 show that the amount of mandatory (Category 11) and the total amount (Category 13) of accounting information was higher during the IAS 14R and IFRS 8 periods than the SSAP 25 period. There are, however, marked differences across individual categories of information and the three periods. The conclusions for the IFRS 8 period also depend on whether the narrow or broad approach is used. Using the narrow approach (which only accounts for accounting information disclosed for operating segments), it would appear that IFRS 8 reduces disclosure volume of 
mandatory and total accounting information, relative to the IAS 14R levels, while the opposite is true if the broad measure is used.

For parsimony, hereafter we only summarise the findings about the most value-relevant and important, from investors’ perspective, types of segmental accounting information: sales (Category 1 in Table 3), assets (Category 3) and profits (Category 5). ${ }^{17}$

Segmental Sales (Category 1). Using the narrow approach, it would appear that IFRS 8 is associated with disclosure of the lowest, across the three standards, amount of LOB and geographic segment sales information. More of this type of information was disclosed during the IAS 14R period, and even more during the SSAP 25 period. However, the opposite result is observed if the broad approach is used (which also accounts for accounting information in entity-wide disclosures), with the highest volume of sales information under IFRS 8. Overall, it appears that IAS 14R and, to a greater extent, IFRS 8 provided investors with a lower amount of segmental sales information than SSAP 25. The extent of the reduction in the amount of per-firm segmental sales information was particularly dramatic for the geographic dimension: from 5.1 under SSAP 25 to 1.4 under IAS 14R and 1.1 under IFRS 8. When incorporating information in the entity-wide disclosures, the amount of geographic sales information reported under IFRS 8 is similar, if marginally higher, to that reported by UK companies under SSAP 25.

Segmental Assets (Category 3). Under the narrow approach, IFRS 8 results in a substantially lower amount of disclosed segmental assets data (both on LOB and, even more so, on geographic segments) compared to the amounts disclosed during the IAS 14R and SSAP 25 periods. However, under the broad approach, the conclusions are different, with the largest amount of asset information disclosed during the IFRS 8 period. These patterns are almost identical to those of sales, as discussed above.

Segmental Profit (Category 5). The adoption of IAS 14R had a major detrimental impact on the disclosure of segmental profit data; this did not improve with the adoption of IFRS 8. Companies 
disclosed three times more geographic profit information under SSAP 25 than they did under IAS 14R and IFRS 8. As profit data are not reported in entity-wide disclosures, the number of profit line items is very similar whether we adopt the narrow or broad definition of segments under IFRS 8 . IFRS 8 and IAS 14R also resulted in a small decrease in the volume of LOB segmental profit information. Similar patterns are observed with regard to the volume of Profit and loss in associates data (Column 6). Overall, IAS 14R and IFRS 8 are associated with a major decrease in the volume of segmental profit information, which was particularly acute for the geographic dimension.

While our results show that the total amount of segmental accounting information disclosed under IAS 14R and IFRS 8 substantially exceeded that disclosed under SSAP 25, this may not necessarily imply informational benefits to investors, as different segmental accounting data items may be of different levels of importance to investors. Information that allows investors to evaluate the performance/profitability of individual segments would be more important to them than other segmental accounting information. Table 4 shows the volume of profitability data that investors would be able to generate using the reported segmental data.

Table 4 about here

Results in Table 4 show that both IAS 14R and IFRS 8 resulted in major reductions in the volume of segment profitability information, compared to that under SSAP 25. While investors would have been able to compute on average six segmental profit margin data items per firm under SSAP 25, upon the adoption of IAS 14R and then IFRS 8 this dropped to less than four, as profit data does not have to be disclosed for secondary segments under IAS 14R or as part of IFRS 8's entity-wide disclosures. Therefore, while profit margins could be computed for over $90 \%$ of reported segments under SSAP 25 , under IAS $14 \mathrm{R}$ this could be done for approximately $60 \%$ of segments. Treating entity-wide disclosures as if they are segments (the broad approach) results in a further reduction in the proportion of segments for which profit margin can be calculated under IFRS 8, to 54\%. The decline in the volume of profitability information is even more dramatic for geographic segments. The number of 
profit margin data items per firm decreased from around three during the SSAP 25 period to approximately one during the IAS 14R and IFRS 8 periods. Similarly, the percentage of geographic segments for which investors could compute profitability dropped from over $80 \%$ under SSAP 25 to 25\% under IAS 14R, and to 20\% under IFRS 8.

Overall, IAS 14R and IFRS 8 clearly surpass SSAP 25 both in terms of the number of segments reported and the volume of segmental accounting information disclosed by UK firms. However, both IAS 14R and IFRS 8 resulted in major decreases in the volume of information on segmental performance - arguably one of the most important types of segmental information for investors. This loss was particularly acute for the geographic dimension. The relative merit of IFRS 8 and IAS 14R as compared to SSAP 25, from users' perspective, is therefore questionable.

\section{Summary and conclusions}

Segment reporting requirements for listed UK companies changed twice in the last decade - from SSAP 25 to IAS 14R upon the adoption of International Accounting Standards in 2005, and again in 2009, when IFRS 8 superseded IAS 14R. SSAP 25, IAS 14R and IFRS 8 differ significantly in the underlying principle of segment identification, the types of segments required for reporting and the types and quantity of accounting data items to be reported per segment. There were also differences in regulators' motivations behind the introduction of each standard: the adoption of SSAP 25 was primarily motivated by users' need for a greater volume and better quality of segmental information, while the adoption of IAS 14R and, to a larger extent, IFRS 8 was arguably more politically motivated, and aimed at international harmonisation of reporting rules.

This study critically evaluates the merits of IFRS 8 relative to its two predecessors, IAS 14R and SSAP 25, through a longitudinal analysis of segment report disclosures for a sample of 127 large listed UK companies under the three reporting standard regimes. We analyse the impact of each standard on the types, number and nature of segments disclosed, and the types and amount of accounting information disclosed by companies in their segment reports. Our study complements the 
generic findings and conclusions of the IASB's IFRS 8 Post-Implementation Review (PIR) with new evidence from the UK, and offers new evidence to inform IASB's policy making.

In sharp contrast with the conclusions of the PIR, we find that IFRS 8 resulted in a major reduction in the average number of operating segments, relative to both the IAS 14R and SSAP 25 levels. We suggest that this paradox may be due to how different studies treat IFRS 8's entity-wide disclosures. Some of the studies summarised in the PIR treat IFRS 8's entity-wide disclosures as if they are equivalent to secondary segments under IAS 14R. While such treatment is not consistent with the wording of the standard (i.e., entity-wide disclosures are not segments), the approach may have some empirical merit. Indeed, we find that a large proportion of our UK sample firms used their IAS 14R secondary segments as a template for entity-wide disclosures of geographic areas and/or products and services, under IFRS 8. While our research design cannot offer insights into factors that drive companies' disclosure decisions, we conjecture that this disclosure pattern could be due to a number of factors.

First, the secondary LOB or geographic segments reported under IAS 14R were not actual (but rather 'artificial') segments, and preparers moved this information into entity-wide disclosures upon the transition to IFRS 8. Second, preparers lacked clear understanding of the nature of entity-wide disclosures and interpreted this as secondary segment-type disclosure. Third, to minimise information production costs, preparers chose to use the previously reported secondary segments as a blueprint for entity-wide disclosures. Adopting a broad approach to segment definition, similar to that adopted by prior studies discussed in the PIR, we find that the introduction of IFRS 8 has resulted in a significant increase in the number of segments. The overall quantity of accounting information disclosed in segment reports is also substantially higher under IFRS 8 and IAS 14R than SSAP 25.

However, while the total volume of segment information increased with the introduction of each new standard, both IFRS 8 and IAS 14R are associated with a major reduction (compared to the SSAP 25 levels) in the quantity of disclosure of segmental profit information for line of business (LOB) and 
even more notably for geographic segments. While segment-level performance data may arguably be the most important accounting information type for investors, companies appear to be reluctant to provide such information - possibly for proprietary cost reasons. Importantly, the reduction in disclosure of segmental profit information occurred upon the transition from SSAP 25 to IAS 14R (as no profit data had to be reported for secondary segments), while there were only small differences between the IAS 14R and IFRS 8 levels (even if one includes the entity-wide disclosures in the analysis). It is, therefore, not surprising that studies that only compare information disclosure quantities under IAS 14R vs. IFRS 8 do not observe this loss of geographic profit data.

Finally, we document evidence that the reported geographic operating segments (under IFRS 8) and geographic primary segments (under IAS 14R) tend to be more broadly defined compared to geographic secondary segments and geographic segments reported under IAS 14R and SSAP 25, respectively. This suggests that companies choose to use more broadly defined geographic areas when they are required to disclose more detailed accounting information (including profit data), which is consistent with the predictions of the Proprietary Costs Theory. Our findings on the geographic dimension complement similar findings on the LOB dimension in prior literature on the impact of competitive disadvantages on managers’ LOB segment reporting choices.

Overall, our findings cast doubt on the effectiveness of IAS 14R and IFRS 8 in improving investors' information environment. Despite the possible benefits (to investors) of the increased overall quantity of information disclosed under IFRS 8, and that IFRS 8 can help investors see companies through the eyes of management, SSAP 25 arguably better served investors’ needs for geographic information. 


\section{Appendix}

\section{Brief summary of key features of SSAP 25, IAS 14R and IFRS 8}

\begin{tabular}{lll}
\hline $\begin{array}{c}\text { SSAP 25 } \\
\text { (mandatory from 1991 to 2005) }\end{array}$ & $\begin{array}{c}\text { IAS 14R } \\
\text { (mandatory from 2005 to 2009) }\end{array}$ & $\begin{array}{c}\text { Ifros of segment identification and measurement of segment information } \\
\text { (mandatory from 2009) }\end{array}$ \\
\hline $\begin{array}{l}\text { Should reflect differences in risk, } \\
\text { returns, growth rates and future } \\
\text { potential }\end{array}$ & $\begin{array}{l}\text { Should reflect predominant } \\
\text { sources of risk and returns, and } \\
\text { have regard for the company's } \\
\text { operational divisions }\end{array}$ & $\begin{array}{l}\text { Management approach, i.e., based } \\
\text { on how segments are determined } \\
\text { internally and reported to (and } \\
\text { reviewed by) chief operating } \\
\text { decision maker (CODM) }\end{array}$ \\
$\begin{array}{lll}10 \% \text { materiality threshold applies } \\
\begin{array}{l}\text { Segmental amounts must be } \\
\text { reported on the same basis as the } \\
\text { entity's financial statements }\end{array}\end{array}$ & $\begin{array}{l}\text { Segmental amounts must be } \\
\text { reported on the same basis as the } \\
\text { entity's financial statements }\end{array}$ & $\begin{array}{l}\text { Segmental amounts are not } \\
\text { required to conform with the basis } \\
\text { of preparation and reporting of the } \\
\text { entity's financial statement }\end{array}$ \\
\hline
\end{tabular}

\begin{tabular}{llll}
\hline & \multicolumn{1}{c}{ Types of segments } & entity’s financial statement \\
\hline$\bullet \quad$ Geographic & $\bullet \quad$ Primary & Operating segments \\
& $\bullet \quad$ Secondary & \\
& & \\
& If primary is based on geography, \\
& secondary should be based on \\
& LOB, and vice versa. \\
\hline
\end{tabular}

\begin{tabular}{lll}
\hline \multicolumn{2}{c}{ Entity-wide disclosures } & \\
\hline None & None & Geographic areas \\
& $\bullet \quad$ Products \& services \\
& & Eajor customers \\
& Entity-wide disclosures are not \\
& part of the management approach
\end{tabular}

\begin{tabular}{|c|c|c|}
\hline \multicolumn{3}{|c|}{ Accounting data to be disclosed } \\
\hline $\begin{array}{l}\text { For each segment: } \\
\text { - } \quad \text { Results } \\
\text { - } \quad \text { Revenues } \\
\text { - } \quad \text { Net assets } \\
\text { If material and/or non- } \\
\text { prejudicial: } \\
\text { - intersegment revenues } \\
\text { - } \quad \text { share of the profit/loss and } \\
\quad \text { assets of associates }\end{array}$ & $\begin{array}{ll}\text { For primary segments: } \\
\text { - } \quad \text { External and intersegment } \\
\text { - } \quad \text { revenues } \\
\text { - } \quad \text { Assets } \\
\text { - } \quad \text { Liabilities } \\
\text { - } \quad \text { Capital expenditures } \\
\text { - } \quad \text { Depreciation and } \\
\text { - } \quad \text { Nomortisation expense } \\
\text { - } \quad \text { depreciation and amortisation } \\
\text { Eenuity method and joint } \\
\text { For secondary segments: } \\
\text { - } \quad \text { Revenues } \\
\text { - } \quad \text { Assets } \\
\text { Capital expenditures }\end{array}$ & $\begin{array}{l}\text { For operating segments: } \\
\text { - } \quad \text { Profit/loss } \\
\text { - } \quad \text { Assets* } \\
\text { - } \quad \text { Riabilities* } \\
\text { - } \quad \text { Intersegment revenues* } \\
\text { - } \quad \text { Interest revenue/expense* } \\
\text { - } \quad \text { Depreciation and } \\
\text { - } \quad \text { amortisation* } \\
\text { - } \quad \text { equity method associates* } \\
\text { Investment in equity method } \\
\text { - } \quad \text { Othec non-cash items* } \\
\text { - } \quad \text { Reconciliations to the entity's } \\
\text { amounts } \\
\text { For entity-wide disclosures: } \\
\text { For geographic areas:** } \\
\text { - } \quad \text { Revenues and non-current } \\
\text { assets for (i) the country of } \\
\text { domicile and (ii) all other }\end{array}$ \\
\hline
\end{tabular}


foreign countries in total

- Revenues and non-current assets for material individual foreign countries

For products \& Services:**

- Revenues

For main customers:

- Revenues

* To be disclosed if such amounts are provided to or reviewed by CODM. ** Unless information is not available and the cost to develop it is excessive. 


\section{Notes}

${ }^{1}$ Nichols et al. (2012) also discuss the debate surrounding the adoption of IFRS 8.
${ }^{2}$ Studies arguing for the importance of segment information include e.g., Mautz (1968), Roberts (1989), Boatsman et al. (1993), McConnell and Pacter (1995), Maines et al. (1997), Street et al. (2000), Herrmann and Thomas (2000), Bodnar et al. (2003), Paul and Largay (2005) and Veron (2007).

${ }^{3}$ Standards vary in their terminology regarding lines of business segments, from 'classes of business' in SSAP 25 to business segments in IAS 14R and business activities in IFRS 8. As in prior literature (e.g., Street et al., 2000; Herrman and Thomas, 2000; Berger and Hann, 2003), we use LOB to refer to business segments.

${ }^{4}$ However, SFAS 14 also required the disclosure of depreciation, capital expenditures and equity in the net income and assets of associates for industry segments.

${ }^{5}$ A more detailed summary of the deliberations and processes that led to the issuance of IAS $14 \mathrm{R}$ can be found in Street and Nichols (2002).

${ }^{6}$ IFRS 8 only differs from SFAS 131 in that it does not require segment reporting in interim reports, it requires the reporting of segment liabilities (if this information is provided to management) and it defines segmental assets as "non-current assets", which includes intangible assets.

${ }^{7}$ Crawford et al. (2013) point out that in informing its decision to converge with SFAS 131, the IASB used evidence from US studies showing that segment disclosures under SFAS 131 improved predictive accuracy and were quickly impounded into share prices. They point out at the problem of relying upon the US evidence on SFAS 131 vs. SFAS 14 as a proxy for IFRS 8 vs. IAS 14R analysis, because although the disclosure requirements of IFRS 8 and SFAS 131 are nearly identical, the requirements of IAS 14R are different from those of SFAS 14.

${ }^{8}$ Nichols et al. (2012) examine the impact of IFRS 8 in a sample of 14 European countries, not including the UK.

${ }^{9}$ Crawford et al. (2012) treat the IFRS 8 entity-wide disclosures as segments but do not discuss the reasons for doing so. Our study, however, demonstrates the rationale for treating the entity-wide disclosures as segments and, furthermore, reports two sets of results, with and without the entity-wide disclosures being treated as segments.

${ }^{10}$ Segment information production costs can be another factor, though this would not be the case for very large companies, which are the subject of our analysis, hence we do not consider this factor in our study. 
${ }^{11}$ Although the 127 companies account for less than $25 \%$ of the total number of non-financial companies listed on the London Stock Exchange, they account for close to $90 \%$ of the market capitalisation of all non-financial segment-reporting constituents of the FTSE All Share index.

${ }^{12}$ The products/services areas reported under entity-wide disclosure are different from the reported business operating segments. There is, thus, no double counting when products/services areas are treated as segments under the broad approach. For example, Antofagasta PLC reports seven business operating segments (Los Pelambres, El Tesoro, Michilla, Esperanza, Exploration and evaluation, Railway and other transport services, and Water concession) and four products/services areas (Copper, Molybdenum, Silver and Gold). The company also reported nine geographic areas under entity-wide disclosures.

${ }^{13}$ Because line items of similar accounting substance may have different names under different standards, we group all segmental accounting line items into broadly defined categories that capture their accounting substance. For example, all segmental sales-related definitions (e.g., the sales by origin and sales by destination items of SSAP 25, the revenue from external customers item of IAS 14R and the revenues from external customers item of IFRS 8) are denoted as sales.

${ }^{14}$ The results for 2003 are very similar to those of 2002 and 2004 (SSAP 25 years), and those of 2007 are very similar to those of 2006 and 2008 (IAS 14R years). To simplify the tables, data for years 2003 and 2007 are not reported, but are available upon request.

${ }^{15}$ IAS 14R required the disclosure of a substantially greater volume of accounting information for primary segments than for secondary segments.

${ }^{16}$ An alternative explanation may be that the firms' internal reporting and organisational structures tended to be organised along business lines rather than geographic dimensions.

${ }^{17}$ Valuation literature demonstrates that earnings (profit) and book value (assets) are the primary inputs in accounting-based valuation models, and analyst literature suggests that earnings, sales and assets are the most important accounting information types for analysts (Garrod and Rees, 1998; Breton and Taffler, 2001). 


\section{Acknowledgements}

We are grateful to Gillian Maciver for help with the data collection. We are grateful to Clive Emmanuel, Claire Roberts, Vivien Beattie, Günther Gebhardt, Pauline Weetman, the editors and an anonymous reviewer for helpful comments and suggestions. We are also grateful to the participants at the 2013 European Accounting Association Congress (Paris), the 2013 British Accounting and Finance Association Conference (Newcastle) and the 2013 International Workshop on Accounting and Regulation (Siena) for their suggestions on the earlier versions of the paper. All errors are the sole responsibility of the authors. 


\section{References}

Accounting Standards Committee (ASC) (1990) Statement of Standard Accounting Practice, No 25, Segmental Reporting, June, ASC: London.

André, P., Filip, A., and Moldovan, R. (2013) The Interplay between Segment Disclosure Quantity and Quality. Retrieved from SSRN http://dx.doi.org/10.2139/ssrn.2470466

Armitage, S., and Marston, C. (2008) Corporate disclosure, cost of capital and reputation: Evidence from finance directors, British Accounting Review, 40, pp. 314-336. doi:10.1016/j.bar.2008.06.003

Association for Investment Management and Research (AIMR) (1993) Financial reporting in the 1990s and beyond: A position paper of the Association for Investment Management and Research, Prepared by Knutson, P. H., Charlottesville, VA.

Berger, M., and Hann, R. (2003) The impact of SFAS 131 on information and monitoring, Journal of Accounting Research, 41, pp. 163-233. DOI: 10.1111/1475-679X.00100

Berger, M., and Hann, R. (2007) Segment Profitability and the Proprietary and Agency Costs of Disclosure, The Accounting Review, 82, 869-906. http://dx.doi.org/10.2308/accr.2007.82.4.869

Boatsman, J., Behn, B., and Patz, D. (1993) A test of geographical segment disclosures, Journal of Accounting Research, 31, pp. 46-64. Retrieved from http://www.jstor.org/stable/2491163

Bodnar, G., Tang, C., and Weintrop, J. (2003) The value of corporate international diversification, Working Paper, John Hopkins University. Retrieved from http://www.academia.edu/2892049/The value of corporate international diversification

Botosan, C., and Stanford, M. (2005) Managers' motives to withhold segment disclosures and the effect of SFAS No. 131 on analysts' information environment, The Accounting Review, 80, pp. 751-771. Retrieved from http://www.jstor.org/stable/4093175

Bouwman, M., Frishkoff, P., and Frishkoff, P. (1987) How do financial analysts make decisions? A process model of the investment screening decision, Accounting, Organisations and Society, 12, pp. 1-30. doi:10.1016/0361-3682(87)90013-4 
Breton, G., and Taffler, R. (2001) Accounting information and analyst stock recommendation decisions: a content analysis approach, Accounting and Business Research, 31, pp. 91-101. DOI:10.1080/00014788.2001.9729604

The Committee on Economic and Monetary Affairs (2007) European Parliament resolution of 14 November 2007 on the draft Commission regulation amending Regulation (EC) No 1725/2003 adopting certain international accounting standards in accordance with Regulation (EC) No 1606/2002 of the European Parliament and of the Council as regards International Financial Reporting Standard (IFRS) 8, concerning disclosure of operating segments. Retrieved from http://www.europarl.europa.eu/sides/getDoc.do?type=TA\&language=EN\&reference=P6-TA$\underline{2007-0526}$

Companies Act (1985). London.

Crawford, L., Extance, H., Helliar, C., and Power, D. (2012) Operating segments: The usefulness of IFRS 8. ICAS Report. ICAS: Edinburgh. Retrieved from http://icas.org.uk/crawford/

Crawford, L., Ferguson, J., Helliar, C., and Power, D. (2014) Control over accounting standards within the European Union: The political controversy surrounding the adoption of IFRS. Critical Perspectives on Accounting, 25, pp. 304-318. doi:10.1016/j.cpa.2013.03.001

Crawford, L., Helliar, C., and Power, D. (2013) Stakeholder views on the usefulness of IFRS 8: did the IASB favour preparers? Working paper.

Emmanuel, C., and Garrod, N. (1992) Segment Reporting: International Issues and Evidence. Prentice Hall-ICAEW.

Emmanuel, C., and Garrod, N. (1994) Segmental reporting in the UK: How does SSAP 25 stand up to international comparison? The European Accounting Review, 2, pp. 547-562. DOI:10.1080/09638189400000035

Emmanuel, C., and Garrod, N. (1999) On segment identification, relevance and comparability, Working paper 99/2, University of Glasgow. Retrieved from https://daedalus.lib.gla.ac.uk/retrieve/191/992\%5B1\%5D.pdf

Emmanuel, C., and Garrod, N. (2002) On the relevance and comparability of segmental data, Abacus, 38, pp. 215-234. DOI: 10.1111/1467-6281.00106 
Emmanuel, C., Garrod, N., McCallum, C., and Rennie, E. (1999) The impact of SSAP 25 and the 10\% materiality rule on segment disclosure in the UK, British Accounting Review, 31, pp. 127-149. doi:10.1006/bare.1998.0090

Ettredge, M., Kwon, Y., Smith, D., and Zarowin, P. (2005) The impact of SFAS No. 131 business segment data on the market's ability to anticipate future earnings, The Accounting Review, 80, pp. 773-804. Retrieved from http://www.jstor.org/stable/4093176

Ettredge, M., Kwon, Y., Smith, D., and Stone, M. (2006) The Effect of SFAS No. 131 on the Crosssegment Variability of Profits Reported by Multiple Segment Firms, Review of Accounting Studies, 11, pp. 91-117. Retrieved from http://link.springer.com/article/10.1007\%2Fs11142-0066397-9\#page-1

European Communities (2002) Regulation (EC) No 1606/2002 of the European Parliament and of the Council, of 19 July 2002, on the application of international accounting standards.

Financial Accounting Standards Board (FASB) (1976) Statement of Financial Accounting Standards No. 14 - Financial Reporting for Segments of a Business Enterprise, Stamford.

Financial Accounting Standards Board (FASB) (1997) Statement of Financial Accounting Standards No. 131 - Disclosures About Segments of an Enterprise and Related Information, Norwalk.

Garrod, N., and Rees, W. (1998) International Diversification and Firm Value, Journal of Business Finance and Accounting, 25, pp. 1255-1281. DOI: 10.1111/1468-5957.00236

Gray, S. and Roberts, C. (1988) Voluntary information disclosure and the British multinationals: Corporate perceptions of costs and benefits. In: Hopwood, A. G. (Ed.), International pressures for accounting change. London (Prentice Hall).

Harris, M. (1998) The association between competition and managers' business segment reporting decisions, Journal of Accounting Research, 36, pp. 111-128. Retrieved from http://www.jstor.org/stable/2491323

Herrmann, D., and Thomas, W. (2000) An analysis of segmental disclosures under SFAS No. 131 and SFAS No. 14, Accounting Horizons, 14, pp. 287-302. Retrieved from http://web.a.ebscohost.com.ezproxy.lib.gla.ac.uk/ehost/pdfviewer/pdfviewer?vid=5\&sid=5740b2 b0-0eaf-4788-a0e1-613b162a911c\%40sessionmgr4002\&hid=4101 
Hope, O-K., and Thomas, W. (2008) Managerial empire building and firm disclosure, Journal of Accounting Research, 46, pp. 591-626. Retrieved from http://www.jstor.org/stable/40058147

Hope, O-K., Kang, T., Thomas, W., and Vasvari, F. (2008) Pricing and mispricing effects of SFAS 131, Journal of Business Finance and Accounting, 35, pp. 281-306. DOI: 10.1111/j.14685957.2007.02071.X

Hussain, S. (2007) Any other suggestions? (segmental reporting), Accountancy, 140(1367), pp. 82-83. International Accounting Standards Board (IASB) (2006) International Financial Reporting Standard 8 - Operating Segments, International Accounting Standards Committee Foundation, January, London.

International Accounting Standards Board (IASB) (2013) Post-implementation Review: IFRS 8 Operating Segments, Report and Feedback Statement, International Accounting Standards Committee Foundation, July, London.

International Accounting Standards Committee (IASC) (1981) International Accounting Standard No. 14: Reporting Financial Information by Segment, London.

International Accounting Standards Committee (IASC) (1997) International Accounting Standard No. 14 (Revised): Segment Reporting, London.

Leuz, C. (2004) Proprietary versus Non-Proprietary Disclosures: Evidence from Germany. In C. Leuz, D. Pfaff, and A. Hopwood (Eds.), The Economics and Politics of Accounting: International Perspectives on Research Trends, Policy and Practice. Oxford University Press (pp. 164-197).

Maines, L., McDaniel, L., and Harris, M. (1997) Implications of proposed segment reporting standards for financial analysts' investment judgements, Journal of Accounting Research, 35 (Supplement), pp. 1-24. Retrieved from http://www.jstor.org/stable/2491450

Moldovan, R. (2014) Post-implementation reviews for IASB and FASB standards: a comparison of the process and findings for the operating segments standards, Accounting in Europe, 11, pp. 113137. DOI:10.1080/17449480.2014.901588

Mautz, K. (1968) Financial reporting by diversified companies. New York: Financial Executives Research Foundation. 
McConnell, P., and Pacter, P. (1995) IASC and FASB proposals would enhance segment reporting, $\begin{array}{llllll}\text { CPA Journal, } & \text { 65(8), } & \text { pp. } & \text { 32-39. } & \text { Retrieved }\end{array}$ http://www.nysscpa.org/cpajournal/1995/AUG95/F320995.htm

Mitchell, A. (2007) Accountability of multinational companies, Parliamentary motion of 2007, April 27. Retrieved from http://www.parliament.uk/edm/2006-07/1369

Nichols, N., and Street, D. (2007) The relationship between competition and business segment reporting decisions under the management approach of IAS 14 Revised, Journal of International Accounting, Auditing and Taxation, 16, pp. 51-68. doi:10.1016/j.intaccaudtax.2007.01.002

Nichols, N., Street, D., and Cereola, S. (2012) An analysis of the impact of adopting IFRS 8 on the segment disclosures of European blue chip companies, Journal of International Accounting, Auditing and Taxation, 21, pp. 79-105. doi:10.1016/j.intaccaudtax.2012.07.001

Nichols, N., Street, D., and Gray, S. (2000) Geographic segment disclosures in the United States: reporting practices enter a new era, Journal of International Accounting, Auditing \& Taxation, 9, pp. 59-82. doi:10.1016/S1061-9518(00)00025-2

Nichols, N., Street, D., and Tarca, A. (2013) The impact of segment reporting under the IFRS 8 and SFAS 131 management approach: a research review, Journal of International Financial Management \& Accounting, 24, pp. 261-312. DOI: 10.1111/jifm.12012

Paul, J., and Largay, J. (2005) Does the “management approach” contribute to segment reporting transparency? Business Horizons, 48, pp. 303-310. doi:10.1016/j.bushor.2004.10.017

Prather-Kinsey, J., and Meek, G. (2004) The effect of revised IAS 14 on segment reporting by IAS companies, European Accounting Review, 13, pp. 213-234. DOI: 10.1080/0963818032000138206

Prencipe, A. (2004) Proprietary Costs and Determinants of Voluntary Segment Disclosure: Evidence from Italian Listed Companies, European Accounting Review, 13, pp. 319-340. DOI: $10.1080 / 0963818042000204742$

Previts, G., Bricker, R., Robinson, T., and Young, S. (1994) A Content Analysis of Sell-Side Financial Analyst Company Reports, Accounting Horizons, 8, pp. 55-70. Retrieved from http://web.a.ebscohost.com.ezproxy.lib.gla.ac.uk/ehost/pdfviewer/pdfviewer?vid=2\&sid=a753f68 
PricewaterhouseCoopers (PwC) (2007, November) Corporate reporting: Is it what investment professionals expect? Report. Retrieved from http://www.pwc.no/no/ifrs/publikasjoner/corporatereporting.jhtml

Roberts, C. (1989) Forecasting earnings using geographical segment data: some UK evidence, Journal of International Financial Management and Accounting, 1, pp. 130-151. DOI: 10.1111/j.1467646X.1989.tb00007.x

Smiley, R. (1988) Empirical Evidence on Strategic Entry Deterrence, Journal of Industrial Organization, 6, pp. 167-180. doi:10.1016/S0167-7187(88)80023-7

Scott, T. (1994) Incentives and Disincentives for Financial Disclosure: Voluntary Disclosure of Defined Benefit Pension Plan Information by Canadian Firms, The Accounting Review, 69, pp. 26-43. Retrieved from http://www.jstor.org/stable/248259

Street, D., and Nichols, N. (2002) LOB and geographic segment disclosures: an analysis of the impact of IAS 14 revised, Journal of International Accounting Auditing and Taxation, 11, pp. 91-113. doi:10.1016/S1061-9518(02)00072-1

Street, D., Nichols, N., and Gray, S. (2000) Segment disclosures under SFAS No. 131: has business segment reporting improved? Accounting Horizons, 14, pp. 259-285. Retrieved from http://web.b.ebscohost.com.ezproxy.lib.gla.ac.uk/ehost/pdfviewer/pdfviewer?vid=2\&sid=90758f1 4-2740-4b45-9a8d-0981093b3623\%40sessionmgr114\&hid=101

Sukhraj, P. (2007) Segment reporting row hots up. Retrieved from http://www.accountancyage.com/aa/analysis/1782542/segment-reporting-row-hots

Veron, N. (2007) EU adoption of the IFRS 8 standard on operating segments. Report to the Economic and Monetary Affairs Committee of the European Parliament. Retrieved from http://www.bruegel.org/publications/publication-detail/publication/21-eu-adoption-of-the-ifrs-8$\underline{\text { standard-on-operating-segments/ }}$

Verrecchia, R. (1983) Discretionary disclosure, Journal of Accounting and Economics, 5, pp. 179-194. Retrieved from http://www.personal.psu.edu/sjh11/ACCTG597E/Class21/notUsed/VerrecchiaJAE83.pdf 
Zeff, S. (2008) IFRS developments in the USA and EU, and some implications for Australia, Australian Accounting Review, 18, pp. 275-282. doi: 10.1111/j.1835-2561.2008.0032. 
Table 1. Number of segments reported during SSAP 25, IAS 14R and IFRS 8

\begin{tabular}{|c|c|c|c|c|c|c|c|c|c|c|}
\hline \multirow[b]{3}{*}{ Year } & \multicolumn{2}{|c|}{ SSAP 25} & \multicolumn{2}{|c|}{ IAS 14R } & \multirow{3}{*}{$\begin{array}{r}\text { IFRS8 } \\
2010\end{array}$} & \multicolumn{5}{|c|}{ Statistical significance of change } \\
\hline & & & & & & 2004 & 2006 & 2008 & 2010 & 201 \\
\hline & 2002 & 2004 & 2006 & 2008 & & $\begin{array}{l}\text { vs. } \\
2002\end{array}$ & $\begin{array}{c}\text { vs. } \\
2004\end{array}$ & $\begin{array}{c}\text { vs. } \\
2006\end{array}$ & $\begin{array}{c}\text { vs. } \\
2008\end{array}$ & $\begin{array}{c}\text { vs. } \\
2004\end{array}$ \\
\hline & & & & & & $\begin{array}{l}\text { 足 } \\
\text { 离 } \\
\text { N }\end{array}$ & 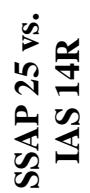 & 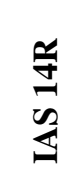 & 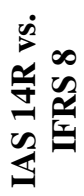 & 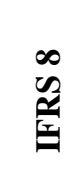 \\
\hline
\end{tabular}

Total sample (127 firms)

Average no. of all

segments per firm

Average no. of

geographic

segments per firm

Average no. of

LOB segments per

firm $\begin{array}{lllll}7.17 & 6.98 & 7.31 & 7.22 & 8.85^{\dagger \dagger} \\ & & & & \end{array}$

$\begin{array}{lllll}3.56 & 3.6 & 3.65 & 3.7 & 4.53^{\dagger \dagger} \\ 1.13^{\dagger}\end{array}$

$\begin{array}{llll}3.61 & 3.39 & 3.65 & 3.52\end{array}$

$4.32^{\dagger \dagger}$
$2.93^{\dagger}$
010

\section{Firms with line-of-business (LOB) as primary basis under IAS 14R (98 firms)}

\begin{tabular}{|c|c|c|c|c|c|c|c|c|c|c|}
\hline $\begin{array}{l}\text { Average no. of all } \\
\text { segments per firm }\end{array}$ & 7.58 & 7.43 & 7.8 & 7.57 & $\begin{array}{l}9.55^{\dagger \dagger} \\
4.07^{\dagger}\end{array}$ & - & - & - & $\begin{array}{l}* * * \\
* * *\end{array}$ & $\begin{array}{c}* \\
* * *\end{array}$ \\
\hline $\begin{array}{l}\text { Average no. of } \\
\text { geographic } \\
\text { segments per firm }\end{array}$ & 3.43 & 3.46 & 3.54 & 3.59 & $\begin{array}{c}4.43^{\dagger \dagger} \\
0.30^{\dagger}\end{array}$ & - & - & - & $\begin{array}{l}* * * \\
* * *\end{array}$ & $\begin{array}{c}* * \\
* * *\end{array}$ \\
\hline $\begin{array}{l}\text { Average no. of } \\
\text { LOB segments per } \\
\text { firm }\end{array}$ & 4.15 & 3.97 & 4.26 & 3.98 & $\begin{array}{c}5.12^{\dagger \dagger} \\
3.77^{\dagger}\end{array}$ & - & - & - & $\begin{array}{c}* * * \\
-\end{array}$ & * \\
\hline
\end{tabular}

Firms with geography as primary basis under IAS 14R (29 firms)

\begin{tabular}{|c|c|c|c|c|c|c|c|c|c|c|}
\hline $\begin{array}{l}\text { Average no. of all } \\
\text { segments per firm }\end{array}$ & 5.79 & 5.48 & 5.66 & 6.03 & $\begin{array}{c}6.48^{\dagger \dagger} \\
4.00^{\dagger}\end{array}$ & - & - & - & $\begin{array}{c}- \\
* * *\end{array}$ & - \\
\hline $\begin{array}{l}\text { Average no. of } \\
\text { geographic } \\
\text { segments per firm }\end{array}$ & 4 & 4.07 & 4.03 & 4.07 & $\begin{array}{c}4.86^{\dagger \dagger} \\
3.93^{\dagger}\end{array}$ & - & - & - & - & - \\
\hline $\begin{array}{l}\text { Average no. of } \\
\text { LOB segments per } \\
\text { firm }\end{array}$ & 1.79 & 1.41 & 1.62 & 1.97 & $\begin{array}{l}1.62^{\dagger \dagger} \\
0.07^{\dagger}\end{array}$ & - & - & - & $\begin{array}{c}- \\
* * *\end{array}$ & $\begin{array}{c}- \\
* * *\end{array}$ \\
\hline
\end{tabular}

The table reports the number of segments per firm per year, split between geographic and line-of-business (LOB) segments. The analysis covers the SSAP 25 (2002 and 2004), IAS 14R (2006 and 2008) and IFRS 8 (2010) periods. The significance of the change in the mean number of segments within reporting regimes (2004 vs. 2002 and 2008 vs. 2006) and between regimes (2006 vs. 2004, 2010 vs. 2008 and 2010 vs. 2004) are calculated using differences in means t-test. The analysis is based on a sample of 127 non-financial companies for which we have data in each of the sample years. The sample companies were constituents of the FTSE 100 index at least once during the 2002-2010 period. We exclude 2005 and 2009 as transition years from the analysis. For brevity, we do not report results for 2003 and 2007, but these are available on request. The top panel is based on the full sample of 127 companies, while in the middle and lower panels the analysis is split between firms with LOB and 
geography, respectively, as the primary basis of segmentation under IAS 14R. For IFRS 8 the results are reported based on a narrow and broad interpretation of segments: ${ }^{\dagger}$ Under the narrow approach only the reported operating segments are treated as segments. ${ }^{\dagger \dagger}$ Under the broad approach all of the entity-wide disclosures are also treated as segments. When the reported operating segments are LOB (i.e., there are no geographic operating segments), the geographic areas reported as entity-wide disclosures are treated and counted as geographic segments. ***, ** and * indicate the statistical significance of the noted difference at, respectively, the $1 \%, 5 \%$ and $10 \%$ levels. 
Table 2: Frequency of geographic segments reported at various levels of aggregation

\begin{tabular}{|c|c|c|c|c|c|c|}
\hline$\underline{\text { Year }}$ & $\underline{2002}$ & $\underline{2004}$ & $\underline{2006}$ & $\underline{2008}$ & $\underline{\mathbf{2 0 1 0}}^{\dagger \dagger}$ & $\underline{\mathbf{2 0 1 0}}^{\dagger}$ \\
\hline \multicolumn{7}{|l|}{ Total sample (127 firms) } \\
\hline $\begin{array}{l}\text { Total number of geographic } \\
\text { segments }\end{array}$ & 452 & 458 & 461 & 470 & 535 & 141 \\
\hline \multicolumn{7}{|l|}{ Percentage in relation to total: } \\
\hline Single-country segments & $30.3 \%$ & $28.4 \%$ & $27.3 \%$ & $28.5 \%$ & $42.6 \%$ & $24.1 \%$ \\
\hline Two-country segments & $2.7 \%$ & $3.3 \%$ & $4.1 \%$ & $4.3 \%$ & $3.4 \%$ & $9.2 \%$ \\
\hline Single-region segments & $35.8 \%$ & $37.8 \%$ & $39.0 \%$ & $36.0 \%$ & $27.7 \%$ & $36.9 \%$ \\
\hline Two-region segments & $16.2 \%$ & $16.2 \%$ & $16.1 \%$ & $17.9 \%$ & $13.3 \%$ & $17.7 \%$ \\
\hline Rest of World segments & $15.0 \%$ & $14.4 \%$ & $13.4 \%$ & $13.4 \%$ & $13.1 \%$ & $12.1 \%$ \\
\hline \multicolumn{7}{|c|}{ Firms with line-of-business (LOB) as primary basis under IAS 14R (98 firms) } \\
\hline $\begin{array}{l}\text { Total number of geographic } \\
\text { segments }\end{array}$ & 336 & 337 & 346 & 349 & 414 & 25 \\
\hline \multicolumn{7}{|l|}{ Percentage in relation to total: } \\
\hline Single-country segments & $28.9 \%$ & $28.5 \%$ & $30.3 \%$ & $31.5 \%$ & $49.8 \%$ & $52.0 \%$ \\
\hline Two-country segments & $2.4 \%$ & $2.1 \%$ & $2.9 \%$ & $2.9 \%$ & $1.7 \%$ & $8.0 \%$ \\
\hline Single-region segments & $36.0 \%$ & $37.1 \%$ & $36.7 \%$ & $33.8 \%$ & $24.2 \%$ & $24.0 \%$ \\
\hline Two-region segments & $17.6 \%$ & $17.2 \%$ & $15.9 \%$ & $18.1 \%$ & $11.4 \%$ & $8.0 \%$ \\
\hline Rest of World segments & $15.2 \%$ & $15.1 \%$ & $14.2 \%$ & $13.8 \%$ & $13.0 \%$ & $8.0 \%$ \\
\hline \multicolumn{7}{|c|}{ Firms with geography as primary basis under IAS 14R (29 firms) } \\
\hline $\begin{array}{l}\text { Total number of geographic } \\
\text { segments }\end{array}$ & 116 & 121 & 115 & 121 & 121 & 116 \\
\hline \multicolumn{7}{|l|}{ Percentage in relation to total: } \\
\hline Single-country segments & $34.5 \%$ & $28.1 \%$ & $18.3 \%$ & $19.8 \%$ & $18.2 \%$ & $18.1 \%$ \\
\hline Two-country segments & $3.4 \%$ & $6.6 \%$ & $7.8 \%$ & $8.3 \%$ & $9.1 \%$ & $9.5 \%$ \\
\hline Single-region segments & $35.3 \%$ & $39.7 \%$ & $46.1 \%$ & $42.1 \%$ & $39.7 \%$ & $39.7 \%$ \\
\hline Two-region segments & $12.1 \%$ & $13.2 \%$ & $16.5 \%$ & $17.4 \%$ & $19.8 \%$ & $19.8 \%$ \\
\hline Rest of World segments & $14.7 \%$ & $12.4 \%$ & $11.3 \%$ & $12.4 \%$ & $13.2 \%$ & $12.9 \%$ \\
\hline
\end{tabular}

The table reports the distributions of geographic segments by the level of specificity of geographic areas. The sample and panels are as per Table 1 above. ${ }^{\dagger}$ The narrow approach as defined in Table $1 .{ }^{\text {t+ }}$ The broad approach as defined in Table 1. 
Categories of segmental accounting information

\begin{tabular}{|c|c|c|c|c|c|c|c|c|c|c|c|c|c|c|}
\hline & & 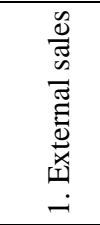 & 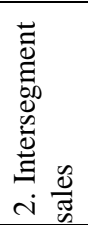 & 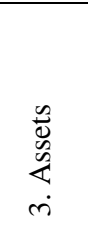 & 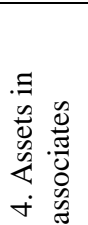 & $\begin{array}{l}\text { Dी } \\
0 \\
0 \\
\text { in }\end{array}$ & 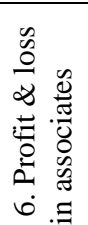 & 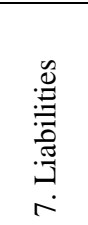 & 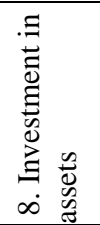 & 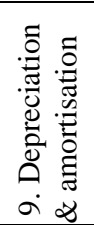 & 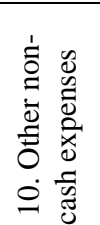 & 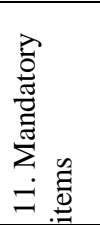 & 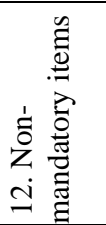 & 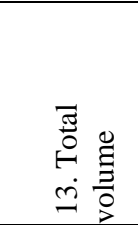 \\
\hline & & & & & & & & & & & & & & SSAP 25 \\
\hline \multirow[t]{3}{*}{2002} & Total & 8.45 & 0.65 & 5.92 & 0.68 & 6.57 & 1.34 & $\mathbf{n} / \mathbf{r}$ & $\mathbf{n} / \mathbf{r}$ & $\mathbf{n} / \mathbf{r}$ & $\mathbf{n} / \mathbf{r}$ & 23.61 & 13.74 & 37.35 \\
\hline & Geographic & 5.05 & 0.28 & 2.85 & 0.35 & 3.12 & 0.59 & $\mathrm{n} / \mathrm{r}$ & $\mathrm{n} / \mathrm{r}$ & $\mathrm{n} / \mathrm{r}$ & $\mathrm{n} / \mathrm{r}$ & 12.23 & 5.39 & 17.61 \\
\hline & LOB & 3.40 & 0.37 & 3.07 & 0.33 & 3.46 & 0.75 & $\mathrm{n} / \mathrm{r}$ & $\mathrm{n} / \mathrm{r}$ & $\mathrm{n} / \mathrm{r}$ & $\mathrm{n} / \mathrm{r}$ & 11.38 & 8.35 & 19.73 \\
\hline \multirow[t]{4}{*}{2004} & Total & 8.40 & 0.61 & 6.02 & 0.63 & 6.45 & 1.31 & $\mathbf{n} / \mathbf{r}$ & $\mathbf{n} / \mathbf{r}$ & $\mathbf{n} / \mathbf{r}$ & $\mathbf{n} / \mathbf{r}$ & 23.43 & 13.99 & 37.42 \\
\hline & Geographic & 5.14 & 0.31 & 2.94 & 0.32 & 3.17 & 0.61 & $\mathrm{n} / \mathrm{r}$ & $\mathrm{n} / \mathrm{r}$ & $\mathrm{n} / \mathrm{r}$ & $\mathrm{n} / \mathrm{r}$ & 12.50 & 5.28 & 17.79 \\
\hline & $\mathrm{LOB}$ & 3.26 & 0.30 & 3.07 & 0.31 & 3.28 & 0.71 & $\mathrm{n} / \mathrm{r}$ & $\mathrm{n} / \mathrm{r}$ & $\mathrm{n} / \mathrm{r}$ & $\mathrm{n} / \mathrm{r}$ & 10.92 & 8.71 & 19.63 \\
\hline & & & & & & & & & & & & & & IAS 14R \\
\hline \multirow[t]{3}{*}{2006} & Total & 7.09 & 1.10 & 7.07 & 0.65 & 4.08 & 0.83 & 3.83 & 6.76 & 3.83 & 2.14 & 37.38 & 7.24 & 44.61 \\
\hline & Geographic & 1.25 & 0.28 & 1.26 & 0.20 & 0.87 & 0.20 & 0.83 & 1.24 & 0.80 & 0.38 & 7.31 & 0.79 & 8.09 \\
\hline & LOB & 5.83 & 0.82 & 5.81 & 0.46 & 3.21 & 0.62 & 3.00 & 5.52 & 3.03 & 1.76 & 30.07 & 6.45 & 36.52 \\
\hline \multirow[t]{4}{*}{2008} & Total & 7.02 & 1.19 & 6.94 & 0.81 & 3.90 & 0.80 & 3.61 & 6.24 & 3.60 & 2.04 & 36.14 & 9.21 & 45.35 \\
\hline & Geographic & 1.39 & 0.24 & 1.34 & 0.27 & 0.93 & 0.24 & 0.88 & 1.23 & 0.85 & 0.51 & 7.87 & 1.16 & 9.03 \\
\hline & LOB & 5.63 & 0.95 & 5.60 & 0.54 & 2.97 & 0.56 & 2.72 & 5.02 & 2.75 & 1.53 & 28.27 & 8.06 & 36.32 \\
\hline & & & & & & & & & & & & & & IFRS 8 \\
\hline \multirow[t]{3}{*}{$2010^{+\dagger}$} & Total & 10.52 & 1.86 & 7.48 & 0.69 & 4.06 & 1.29 & 2.32 & 5.14 & 3.62 & 3.88 & 40.87 & 16.46 & 57.32 \\
\hline & Geographic & 5.69 & 0.34 & 5.04 & 0.24 & 1.12 & 0.33 & 0.61 & 2.64 & 0.91 & 1.09 & 18.02 & 6.88 & 24.90 \\
\hline & LOB & 4.83 & 1.52 & 2.44 & 0.45 & 2.94 & 0.96 & 1.71 & 2.50 & 2.71 & 2.79 & 22.85 & 9.57 & 32.43 \\
\hline \multirow[t]{3}{*}{$2010^{\dagger}$} & Total & 3.96 & 1.86 & 3.26 & 0.69 & 3.97 & 1.29 & 2.32 & 3.29 & 3.62 & 3.88 & 28.14 & 12.90 & 41.04 \\
\hline & Geographic & 1.08 & 0.34 & 0.85 & 0.24 & 1.07 & 0.33 & 0.61 & 0.80 & 0.91 & 1.09 & 7.33 & 3.99 & 11.32 \\
\hline & LOB & 2.88 & 1.52 & 2.41 & 0.45 & 2.90 & 0.96 & 1.71 & 2.49 & 2.71 & 2.79 & 20.81 & 8.91 & 29.72 \\
\hline
\end{tabular}

The table reports the average number of segmental accounting line items (by accounting data type) reported by each company. Categories 1 through 10 capture the accounting line items to be disclosed, when applicable, under each standard. Category 11 represents the total volume of mandatory accounting line items (sum of Categories 1-10). Category 12 captures all other reported non-mandatory accounting line items and Category 13 captures the total volume of all segmental accounting information (sum of Categories 11 \& 12). Note that Categories 7 to 10 were not mandatory during the SSAP 25 period. 
The disclosure requirements under each standard are summarised in the Appendix. ${ }^{\dagger}$ The narrow approach as defined in Table $1 .{ }^{\dagger \dagger}$ The broad approach as defined in Table 1. 
Table 4: Availability of segment-level profitability data

SSAP 25

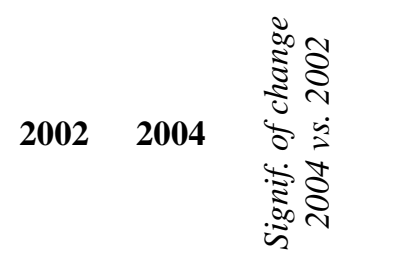

IAS 14R

2006

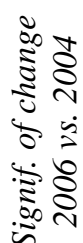

2008

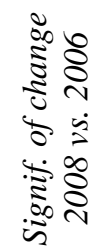

IFRS 8

2010

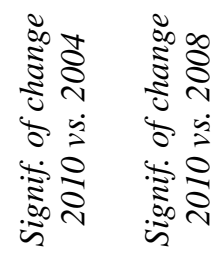

Number of segments per firm with available PM and ROA data:

\section{PM}

\begin{tabular}{lllllllllll} 
Total & 6.27 & 6.04 & - & 3.93 & $* * *$ & 3.76 & - & 3.92 & $* * *$ & - \\
Geographic & 2.97 & 2.97 & - & 0.84 & $* * *$ & 0.85 & - & 1.07 & $* * *$ & - \\
LOB & 3.30 & 3.07 & - & 3.09 & - & 2.91 & - & 2.85 & - & - \\
& & & & & & & & & & \\
ROA & & & & & & & & & & \\
Total & 5.91 & 5.82 & - & 3.83 & $* * *$ & 3.78 & - & 3.22 & $* * *$ & $*$ \\
Geographic & 2.86 & 2.90 & - & 0.83 & $* * *$ & 0.86 & - & 0.84 & $* * *$ & - \\
LOB & 3.05 & 2.92 & - & 2.99 & - & 2.92 & - & 2.38 & $* *$ & $*$ \\
\hline
\end{tabular}

Percentage of segments with available PM and ROA data:

PM

\begin{tabular}{lcccccccccc} 
Total & $90 \%$ & $90 \%$ & - & $60 \%$ & $* * *$ & $58 \%$ & - & $54 \%$ & $* * *$ & - \\
Geographic & $86 \%$ & $85 \%$ & - & $24 \%$ & $* * *$ & $25 \%$ & - & $25 \%$ & $* * *$ & - \\
LOB & $93 \%$ & $93 \%$ & - & $84 \%$ & $* *$ & $80 \%$ & - & $74 \%$ & $* * *$ & - \\
& & & & & & & & & & \\
ROA & & & & & & & & & & \\
Total & $84 \%$ & $86 \%$ & - & $58 \%$ & $* * *$ & $58 \%$ & - & $45 \%$ & $* * *$ & $* * *$ \\
Geographic & $83 \%$ & $83 \%$ & - & $24 \%$ & $* * *$ & $25 \%$ & - & $20 \%$ & $* * *$ & - \\
LOB & $84 \%$ & $88 \%$ & - & $82 \%$ & - & $80 \%$ & - & $63 \%$ & $* * *$ & $* * *$ \\
\hline
\end{tabular}

PM refers to Profit Margin of reported segments, computed as the ratio of segment profit to turnover. ROA refers to Return on Asset of reported segments, computed as the ratio of the segment profit to assets. The top panel shows the per-firm average numbers of segments for which profitability can be calculated. It should be noted that profit data is not required for secondary segments under IAS 14R and for entity-wide disclosures under IFRS 8. The bottom panel is based on the 'broad' definition of segments (i.e., including entity-wide disclosures under IFRS 8) and shows the percentages of segments for which profitability data is available. ***,** and * indicate the statistical significance of the noted difference at, respectively, the $1 \%, 5 \%$ and $10 \%$ levels. 